\title{
Valuable utilization of ferrochrome slag for wastewater treatment
}

\author{
Priyanka Saha* and Supriya Sarkar \\ Environment Research Group, Research and Development, Tata Steel Ltd, Jamshedpur 831 007, India
}

\begin{abstract}
During ferrochrome production, slag is discarded as a waste material in huge quantities. A relatively small percentage finds application whereas majority of the slag is held in dumps. The purpose of the study is valuable utilization of ferrochrome slag. The experimental results showed that $99 \%$ removal of chromium (Cr(VI)) was achieved in $1 \mathrm{~h}$ by ferrochrome slag from Sukinda chromite mines water. There is an in situ generation of ferrous sulphate by the effect of oxidizing agent and iron content of ferrochrome slag which is capable of reducing $\mathrm{Cr}$ (VI) to trivalent chromium. Water samples surrounding the slag dumped area were checked to find out the extent of problem caused by them. There is no adverse effect of $\mathrm{Cr}$ on the surrounding water samples. Toxicity characteristic leaching procedure test revealed that the slag is environmentally stable. This research concludes that used ferrochrome slag could be utilized as a waste water treatment.
\end{abstract}

Keywords: Ferrochrome slag, hexavalent chromium, Sukinda chromite mine, sulphuric acid, wastewater.

HuGE quantity of unmanaged industrial solid waste in the form of slag, ash, char, dust, etc. has resulted in an increased environmental concern. Slags are the main sources of waste, produced in a large quantities in pyro metallurgical processes, have to be recycled and utilized accordingly. Ferrochrome ( $\mathrm{FeCr}$ ) slag is basically a waste in the production of $\mathrm{FeCr}$, which is used in the production of different grades of stainless steel, as the most common alloying material. The raw material used in the $\mathrm{FeCr}$ production are chromite ore, reducing metallurgical coke and fluxing quartzite. The constituents of chrome ore are essentially $\mathrm{Cr}_{2} \mathrm{O}_{3}, \mathrm{FeO}, \mathrm{Al}_{2} \mathrm{O}_{3}, \mathrm{MgO}, \mathrm{CaO}$ and $\mathrm{SiO}_{2}$. Ferrochromium is produced pyro metallurgically by carbothermic reduction of chromite ore $\left(\mathrm{FeO} \cdot \mathrm{Cr}_{2} \mathrm{O}_{3}\right)$. The valuable minerals in the chromium ore are $\mathrm{Cr}_{2} \mathrm{O}_{3}$ and $\mathrm{FeO}$, which are reduced to chromium and iron in the furnace, and make up the sought high-carbon ferrochromium alloy. During FeCr production, slag is discarded as a waste material in huge quantities. A relatively small percentage of this material finds application, but the majority of the slag each year is dumped and as land dis-

\footnotetext{
*For correspondence. (e-mail: priyanka.saha@tatasteel.com)
}

posing costs increase, new disposal options are needed. Rapid urbanization and industrialization have resulted in lesser land availability for landfill and the disposal cost is increasing fast. With the enforcement of stringent environmental regulations, alternative utilization and new disposal techniques of slags to minimize the associated environmental pollution are considered to be the way forward.

Ferrochrome slag is useful as a construction material due to its excellent technical material properties. However, an environmental concern has been raised about the content and leachability of toxic metals, especially chromium. Ferrochromium slag is classified as harmless in terms of International Agency for Research on Cancer (IARC) classification, as the chromium exists in ferrochromium slags as $\mathrm{Cr}(\mathrm{III})^{1}$. Chromium contamination of water is a significant problem since hexavalent form of chromium is highly toxic and potentially carcinogenic to living organisms. Chromium being insoluble and immobile in its trivalent state $(\mathrm{Cr}(\mathrm{III}))$ is nontoxic and used as microelement ${ }^{2-5}$, whereas the hexavalent state $(\mathrm{Cr}(\mathrm{VI}))$ is toxic and a priority pollutant $\mathrm{t}^{2,5-7}$ because of its higher water solubility and the resulting higher mobility. Mobility of $\mathrm{Cr}(\mathrm{VI})$ is highly regulated by $\mathrm{pH}^{8,9}$. In acidic condition, (below pH 5) Cr leaching is contributed by dissolution of $\mathrm{Cr}$ (III) and in basic condition (above $\mathrm{pH} 5$ ), leaching is by $\mathrm{Cr}(\mathrm{VI})^{9}$. The leached amount of $\mathrm{Cr}(\mathrm{VI})$ increases as $\mathrm{pH}$ is increased and the amount is insignificant in acidic environment ${ }^{10}$. Oxidation-reduction potential (Eh) and $\mathrm{pH}$ are the two main important parameters, regulating the chromium content in groundwater ${ }^{11,12}$. $\mathrm{Cr}(\mathrm{VI})$ species predominately exists as chromic acid $\left(\mathrm{H}_{2} \mathrm{CrO}_{4}\right)$ salts, hydrogen chromate anion $\left(\mathrm{HCrO}_{4}^{-}\right)$, chromate anion $\left(\mathrm{CrO}_{4}^{2-}\right)$ and dichromate dianion $\left(\mathrm{Cr}_{2} \mathrm{O}_{7}^{2-}\right)$. At $\mathrm{pH}<3, \mathrm{Cr}^{3+}$ is predominant while for $\mathrm{pH}>7$ the $\mathrm{CrO}_{4}^{2-}$ is prevalent ${ }^{13}$. Several chemical and physical factors like precipitationdissolution, alkalinity, redox potential, complexation, organic carbon content, contact time, liquid to solid ratio, particle size, agitation/mixing, common ion effect, partitioning, type of flow, porosity and temperature, influence the release of $\mathrm{Cr}$ species from the $\mathrm{FeCr}$ slag $^{14}$.

The Sukinda chromite mine (SCM) area in Odisha, India has around $97 \%$ of country's total reserve ${ }^{15}$. In Sukinda, groundwater level is $8-11 \mathrm{~m}$ depth, and gets contaminated with $\mathrm{Cr}(\mathrm{VI})$ from chrome ore mining and atmospheric air ${ }^{16}$. Water discharges from the metal 
mining processes and also leachate and runoff water contaminate nearby water sources. The mining activities in Sukinda has caused $\mathrm{Cr}(\mathrm{VI})$ contamination of groundwater and surface water of up to 0.6 and $3.4 \mathrm{mg} / \mathrm{l}$ respectively ${ }^{17}$. The existing chemical method in use is chemical precipitation by ferrous sulphate and lime. A large amount of chemical sludge generated in this method requires further attention.

Adsorption is considered as the more suitable alternative out of the other available physicochemical methods like precipitation, reduction, ion exchange, co-precipitation for $\mathrm{Cr}(\mathrm{VI})$ remediation ${ }^{18,19}$. Adsorbents like clay minerals, sawdust, charcoal, activated carbon, metal oxides, carbon nanotubes, organic polymers, nanoparticles have been used in $\mathrm{Cr}(\mathrm{VI})$ removal $^{20-23}$, but, many of them have low adsorption capacity, high cost and slow kinetics $5,19,24$. Several studies have shown the use of industrial slag as an adsorbent for removal of heavy metals $^{25-28}$. Erdem et al. ${ }^{25}$ showed the use of FeCr slag in removing $\mathrm{Cr}(\mathrm{VI})$ from aqueous solution with sulphuric acid treatment. Therefore, $\mathrm{FeCr}$ slag could be useful as a reductant for removal of toxic elements.

Therefore, this study aims at valuable utilization of $\mathrm{FeCr}$ slag for analysing physical, chemical and geotechnical characterization and evaluates its utilization for mitigation of chromium content in mines waste water.

\section{Materials and methods}

\section{Materials}

Sukinda chromite mine processed water: Tailing pond recirculating water samples were collected from quarry water storage area of beneficiation plant in SCM. Wastewater analysis was done to quantify physico-chemical parameters like $\mathrm{pH}$, total dissolved solid (TDS), dissolved oxygen (DO), biological oxygen demand (BOD), chemical oxygen demand (COD), $\mathrm{Ca}, \mathrm{Mg}, \mathrm{Cr}(\mathrm{VI}), \mathrm{SO}_{4}^{2-}, \mathrm{Fe}$ before and after the treatment. The value at zero day was denoted as initial value while the value noted after the treatment was indicated by final value. Here, zero day means initial day.

Ferrochrome slag and its characterization: Slag samples were collected from Bramnipal Ferro Alloy plant of Tata Steel Limited, India. The size fraction analysis was carried out in the slag samples and also physical and geotechnical analysis. Chemical elemental characterization was done before and after the treatment for observing the effect of elements on sorption of $\mathrm{FeCr}$ slag. Particle size distribution (PSD) analysis is an important requirement in leaching study and in utilization aspects. PSD of granulated $\mathrm{FeCr}$ slag and lumped slag were determined by standard sieve analysis methods as stipulated in Indian Standard (IS: 2386 (Part I)-1997). For particle size analysis of $\mathrm{FeCr}$ slag, sieve analysis was carried out. Sieve analysis is a procedure to assess PSD of a granular material by allowing the sample to pass through a series of sieves of progressively smaller mesh size and weighing the amount of material that is stopped by each sieve as a fraction of the whole mass.

To find a suitable utilization of FeCr slag, physical and geotechnical characteristics were identified and tested according to IS codes. Standard procedures followed are listed in Table 1.

Collection of water samples surrounding the slag dumping area: Water samples from seven different locations of tube wells around $\mathrm{FeCr}$ slag dumped area were collected and analysed to find out the extent of toxic element contamination to the water wells.

\section{Methods}

$\mathrm{pH}$ of the mines waste water was analysed using a $\mathrm{pH}$ meter (Systronics, India, digital $\mathrm{pH}$ meter, model no. 335). The variation of $\mathrm{pH}$ during experiment with the passage of time was measured.

TDS is a measure of combined content of all inorganic and organic substances contained in a liquid in molecular, ionized or micro-granular (colloidal sol) suspended form. TDS was measured at a regular basis during experiment using TDS meter (Systronics, India, model no. 308).

Hexavalent chromium concentration in ppm was measured in spectrophotometer (Thermo scientific-Genesys $10 \mathrm{~S} \mathrm{UV}-\mathrm{V}$ is spectrophotometer), at $540 \mathrm{~nm}$ wavelength after developing a purple colour by using diphenylcarbazide (DPC) solution according to standard procedure ${ }^{29}$.

Apart from chromium, SCM water contains other elements like $\mathrm{Ca}, \mathrm{Mg}, \mathrm{Fe}, \mathrm{Si}, \mathrm{SO}_{4}^{2-}$, etc. These elemental concentrations in the SCM water were determined before and after experiment by inductively-coupled plasma atomic emission spectroscopy (ICP-AES) (Spectro Arcos). The instrument's working wavelengths were set according to APHA $^{29}$.

Leaching analysis of $\mathrm{FeCr}$ slag was done to find out any adverse effect of chromium leaching or other elements on the surrounding area. Different sizes of slag were taken in a beaker and different quantities of water were mixed with slag and stirred at different time intervals $-1,2,3,4,6$ and $24 \mathrm{~h}$. The water to slag ratio was optimized at $1: 20(20 \mathrm{~g}$ slag in 1 litre of distilled water $^{14}$. $\mathrm{Cr}(\mathrm{VI})$ concentrations were analysed at UV-Vis spectrophotometer at $540 \mathrm{~nm}$ wavelength ${ }^{30}$ and other elemental analysis was done by ICP-AES method ${ }^{31}$.

To understand the toxicity characteristics of chromium of $\mathrm{FeCr}$ slag, toxicity characteristic leaching procedure (TCLP) method was applied. $100 \mathrm{~g}$ of pulverized and sieved (9.5 mm screen) slag with 2 litre of extraction fluid (liquid/solid ratio of $1: 20$ ) in a plastic bottle was kept for 
Table 1. Percentage obtained of different size fractions from the dumped ferrochrome (FeCr) slag

\begin{tabular}{lccccccccc}
\hline Size fraction & $+25 \mathrm{~mm}$ & $+15 \mathrm{~mm}$ & $+10 \mathrm{~mm}$ & $+6 \mathrm{~mm}$ & $+3 \mathrm{~mm}$ & $+2 \mathrm{~mm}$ & $+1 \mathrm{~mm}$ & $-1 \mathrm{~mm}$ & $-0.5 \mathrm{~mm}$ \\
Percentage & 0.87 & 2.8 & 3.8 & 9.4 & 11 & 7.3 & 40 & 9.8 & 12 \\
\hline
\end{tabular}

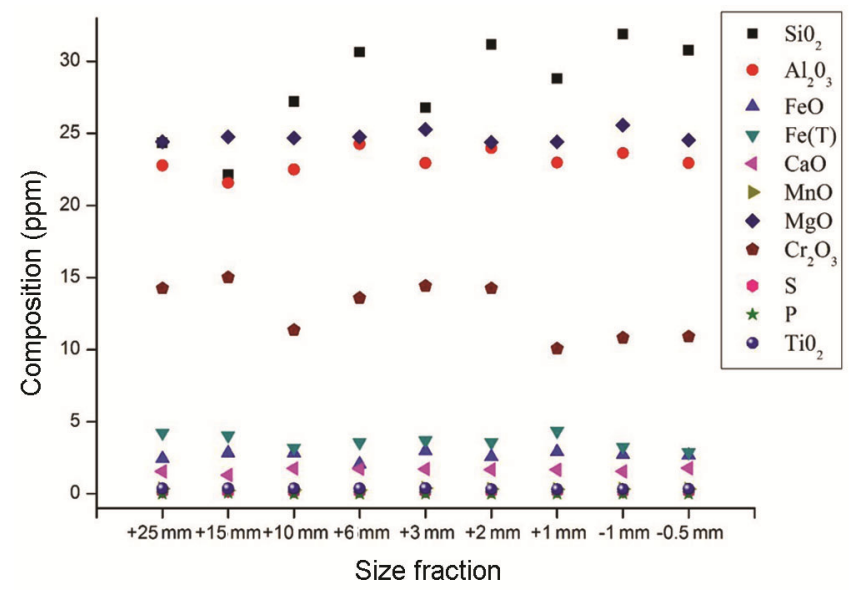

Figure 1. Chemical analysis result of different size fractions of ferrochrome slag.

$24 \mathrm{~h}$ at $18 \mathrm{rpm}$ and filtered using a $0.45 \mu \mathrm{m}$ glass fibre filter. The extraction fluid used was acetic acid-sodium acetate buffer solution ( $\mathrm{pH}=4.93)$. $\mathrm{Cr}(\mathrm{VI})$ concentration in the filtrate was found out by spectrophotometric method at $540 \mathrm{~nm}$ wavelength ${ }^{32}$.

$\mathrm{pH}$ is an inevitable parameter dictating chromium sorption. The method of analysis used for $\mathrm{pH}$ optimization was point of zero charge and variations of solution $\mathrm{pH}$, to find out maximum adsorption of chromium. A solution of $10 \mathrm{~g} / \mathrm{l}$ of $\mathrm{FeCr}$ slag was mixed with electrolyte solution ( 0.01 and $0.1 \mathrm{M} \mathrm{KNO}_{3}$ ). $\mathrm{pH}$ of the solution was adjusted in the range $2.0-12.0$ by $0.5 \mathrm{M} \mathrm{HCl}$ or $0.5 \mathrm{M} \mathrm{NaOH}$. The solutions were shaken for $24 \mathrm{~h}$ at $250 \mathrm{rpm}$ to reach an equilibrium $\mathrm{pH}$ value. The difference of initial $\mathrm{pH}$ and final $\mathrm{pH}$ against solution $\mathrm{pH}$ were plotted for two electrolyte solutions and the intersection point of the two curves gave the point of zero charge. $\mathrm{Cr}(\mathrm{VI})$ removal percentages with variation in $\mathrm{pH}$ were found out by batch experiments done at room temperature $\left(24^{\circ} \pm 2^{\circ} \mathrm{C}\right)$. Fixed masses of slag $(10 \mathrm{~g} / \mathrm{l})$ were shaken at $250 \mathrm{rpm}$ for $24 \mathrm{~h}$ with $5 \mathrm{mg} / \mathrm{l}$ standard potassium dichromate solutions with $\mathrm{pH}$ values varying from 2 to 9 . The solutions after agitation were filtered and analysed for $\mathrm{Cr}(\mathrm{VI})$.

Slag samples were sieved using mesh nos 20, 30 and 36 and used as adsorbent for chromium adsorption. Potassium dichromate $\left(\mathrm{K}_{2} \mathrm{Cr}_{2} \mathrm{O}_{7}\right)$ was used to prepare standard solutions of $\mathrm{Cr}(\mathrm{VI})$ with concentrations in the range 1 to $4 \mathrm{mg} / \mathrm{l}$. Batch experiments were done to find out adsorption characteristics. $\mathrm{pH}$ was set at 2 .

Adsorption isotherms were calculated by treating different concentrations of hexavalent chromium from 1 to $4 \mathrm{mg} / \mathrm{l}$ with an adsorbent dose of $10 \mathrm{~g} / \mathrm{l}$ and $60 \mathrm{~min}$ of equilibration time.
To find the kinetic model, standard solutions in the range $1-4 \mathrm{mg} / \mathrm{l}$ were added to $10 \mathrm{~g} / \mathrm{l}$ slag in water in a series of Erlenmeyer flaks and stirred on a mechanical shaker at $150 \mathrm{rpm}$. While agitating, samples were removed at set time intervals and filtered for analysis.

SCM water contains high amount of chromium content. The reduction of $\mathrm{Cr}(\mathrm{VI})$ was performed by using waste slag and a strong oxidizing agent, sulphuric acid $\left(\mathrm{H}_{2} \mathrm{SO}_{4}\right)$. To get the optimized result, three parameters were varied; water/slag ratio, amount of $\mathrm{H}_{2} \mathrm{SO}_{4}$ and the experimental duration. The water/slag ratios used were $1: 5,1: 10$ and $1: 20$; an amount of $5 \mathrm{M} \mathrm{H}_{2} \mathrm{SO}_{4}$ was varied as 2, 2.5, 3, 4, $5,6,8,10$ and $12 \mathrm{ml}$. Stirring duration was varied at $30 \mathrm{~min}, 1 \mathrm{~h}, 2 \mathrm{~h}$ and $5 \mathrm{~h}$. Used FeCr slag was repeatedly reused in SCM processed water to find out its reusability. The filtered samples were then analysed for $\mathrm{Cr}(\mathrm{VI})$ concentration in spectrophotometric method and $\mathrm{pH}$ and TDS of the samples were also noted.

The mean number of $\mathrm{pH}$, TDS, reduction study of $\mathrm{Cr}(\mathrm{VI})$ of SCM processed water were calculated before and after the experiment and subjected to Student's $t$ test and significant differences were calculated between treatments ${ }^{33}$.

\section{Results and discussion}

\section{Chemical analysis of $\mathrm{FeCr}$ slag}

Chemical analysis of $\mathrm{FeCr}$ slag showed that the major constituents present were $\mathrm{SiO}_{2}(\sim 31 \%), \mathrm{MgO}(\sim 24 \%)$, $\mathrm{Al}_{2} \mathrm{O}_{3}(\sim 24 \%)$ and $\mathrm{Cr}_{2} \mathrm{O}_{3}(\sim 14 \%)$ (Figure 1). In all the size fractions, major constituents were $\mathrm{SiO}_{2}(\sim 25 \%-$ $30 \%), \mathrm{MgO}(\sim 24 \%), \mathrm{Al}_{2} \mathrm{O}_{3}(\sim 22 \%)$ and $\mathrm{Cr}_{2} \mathrm{O}_{3}(\sim 10 \%-$ $14 \%$ ) (Figure 1). Size fraction analysis showed that the size $+1 \mathrm{~mm}$ is present in highest amount (40\%) (Table 1). Our chemical composition results are in close agreement of results obtained by Erdem et al. ${ }^{25}$.

\section{Analysis of water collected from tube wells around $\mathrm{FeCr}$ slag dumped area}

Water samples from tube wells around the $\mathrm{FeCr}$ slag dumping area were analysed to find out leaching of any toxic element, specially $\mathrm{Cr}(\mathrm{VI})$ from the slag dumps. Chemical analysis showed that water of one of the dumping slag area sites (07A) had $\mathrm{Cr}(\mathrm{VI})$ concentration above the permissible limit at about $1.2 \mathrm{ppm}$ (Table 2). The IS permissible limit for $\mathrm{Cr}(\mathrm{VI})$ for drinking water is $0.05 \mathrm{ppm}$ (IS 10500: 2012) with no relaxation. This 
Table 2. Chemical analysis of water samples collected from tube wells around FeCr slag dumped areas

\begin{tabular}{lllllllllll}
\hline Source & $\mathrm{pH}$ & $\mathrm{Cl}$ & $\mathrm{Cu}$ & $\mathrm{Cr}$ & $\mathrm{Ca}$ & $\mathrm{Mg}$ & $\mathrm{Fe}$ & $\mathrm{Na}$ & $\mathrm{K}^{2}$ & $\mathrm{PO}_{4}^{3-}$ \\
\hline NALA & 8.06 & 120.7 & 0.12 & 0.000 & 36 & 90 & 0.001 & 12 & 50 & 0.36 \\
07A & 8.5 & 42.6 & 0.11 & 1.2 & 27 & 65 & 0.001 & 2 & 17 & 0.001 \\
010A & 7.26 & 49.7 & 0.11 & 0.001 & 70 & 37 & 0.02 & 0.001 & 40 & 0.001 \\
T6 & 7.45 & 92.3 & 0.11 & 0.000 & 65 & 43 & 0.11 & 0.001 & 21 & 0.001 \\
T9 & 6.8 & 35.5 & 0.11 & 0.000 & 47 & 23 & 0.75 & 0.001 & 15 & 0.001 \\
T10 & 7.2 & 28.4 & 0.11 & 0.001 & 39 & 19 & 0.001 & 0.001 & 18 & 0.001 \\
T15 & 7.34 & 35.5 & 0.11 & 0.000 & 28 & 10 & 0.001 & 0.001 & 12 & 0.001 \\
013A & 7.15 & 56.8 & 0.11 & 0.001 & 107 & 13 & 0.001 & 11 & 43 & 0.001 \\
\hline
\end{tabular}

All values in ppm except $\mathrm{pH}$.
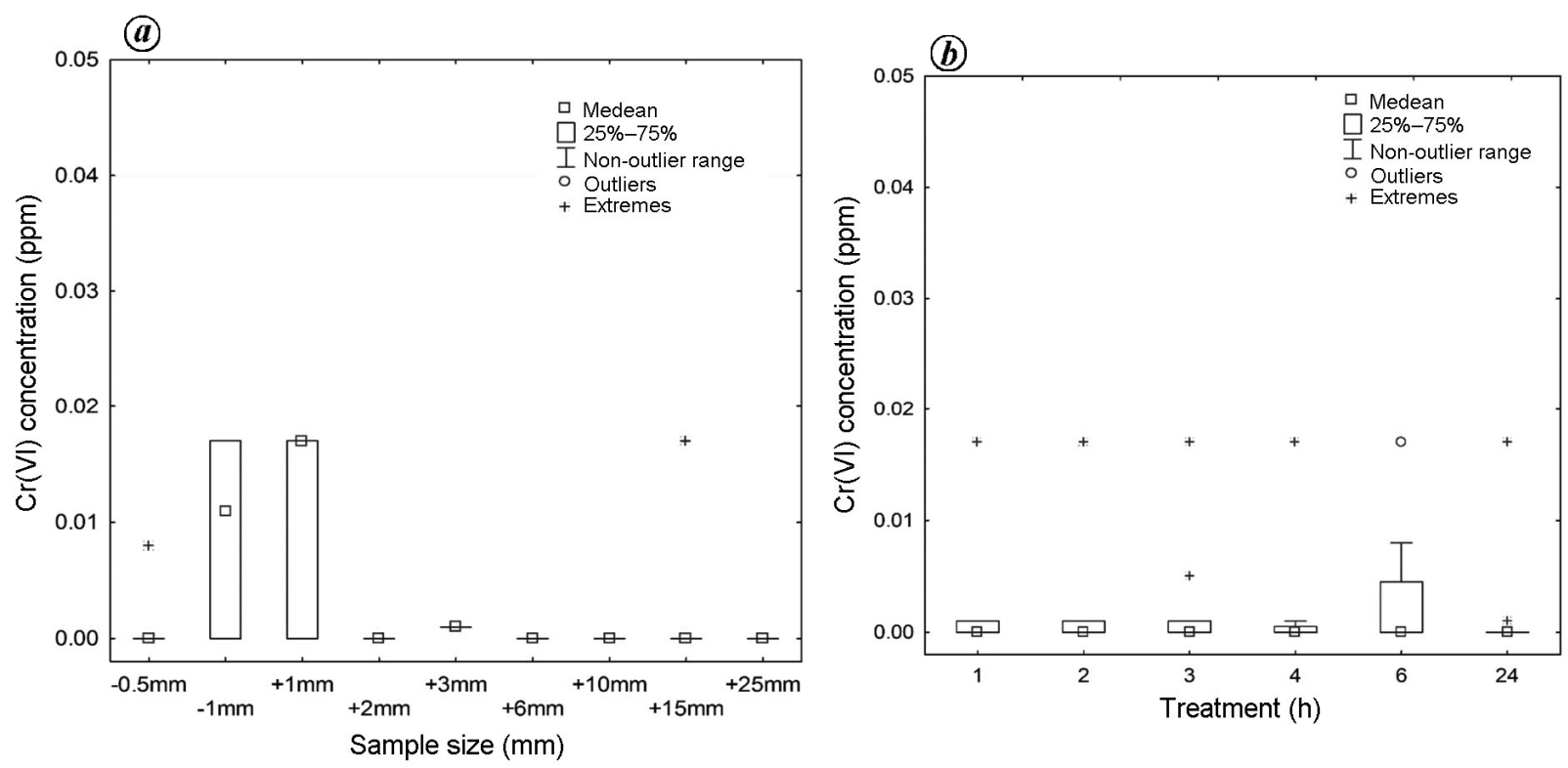

Figure 2. $\boldsymbol{a}$, Leaching analysis of $\mathrm{Cr}(\mathrm{VI})$ from the different size fractions of the FeCr slag. $\boldsymbol{b}$, Leaching analysis of Cr(VI) in water from the slag in neutral $\mathrm{pH}$ condition at different exposure duration of size fraction of $+1 \mathrm{~mm}$.

particular tube well of concern was shut down with immediate effect.

\section{Leaching analysis of $\mathrm{Cr}(\mathrm{VI})$ from $\mathrm{FeCr}$ slag}

Leaching analysis data revealed almost negligible leaching of $\mathrm{Cr}(\mathrm{VI})$ from all size fractions of $\mathrm{FeCr}$ slag (Figure $2 a$ ) and even at different time durations (Figure $2 b$ ). Slag samples are granular and are not soluble in water. The maximum amount of $\mathrm{Cr}(\mathrm{VI})$ leached was $0.017 \mathrm{ppm}$ at a leaching time of $6 \mathrm{~h}$. These results are similar to that obtained by Shadreck and Tawanda ${ }^{34}$, and Tanskanen and Makkonen $^{35}$. One of the two controlling factors of $\mathrm{Cr}$ leaching is the ratio of calcium oxide $(\mathrm{CaO})$ and silicon dioxide $\left(\mathrm{SiO}_{2}\right)$ with the amount of magnesium. When $\mathrm{CaO} / \mathrm{SiO}_{2}$ ratio is less than $2, \mathrm{Cr}$ is present as magnesiochromite spinel phase $\left(\mathrm{MgCr}_{2} \mathrm{O}_{4}\right)$, whereas $\mathrm{Cr}$ exists predominantly as calcium chromite when the ratio is greater than 2 (ref. 36). Magnesiochromite phase is resistant to oxidation and dissolution, however, calcium chromite can be oxidized to calcium chromate and leaching by acid treatment is possible ${ }^{37}$. Chemical constituent analysis showed that $\mathrm{CaO} / \mathrm{SiO}_{2}$ ratio was less than 2 in all the cases. Thus it can be said that the $\mathrm{Cr}$ is in magnesiochromite spinel phase.

\section{Leaching analysis of other elements from $\mathrm{FeCr}$ slag}

Other elemental data showed low leachability of most elements from the slag. Leachate of different size fractions showed negligible leaching of most elements including $\mathrm{Ca}, \mathrm{Mg}, \mathrm{Fe}, \mathrm{K}, \mathrm{Na}, \mathrm{SiO}_{2}, \mathrm{Cr}$. Different sample sizes (Figure $3 a$ ) with different time interval (Figure $3 b$ ) showed all the values within permissible limits according to IS: 10500: 2012. Data analysis result revealed that maximum leaching was observed in sulphate element (around 16-20 ppm) but this was also within the 

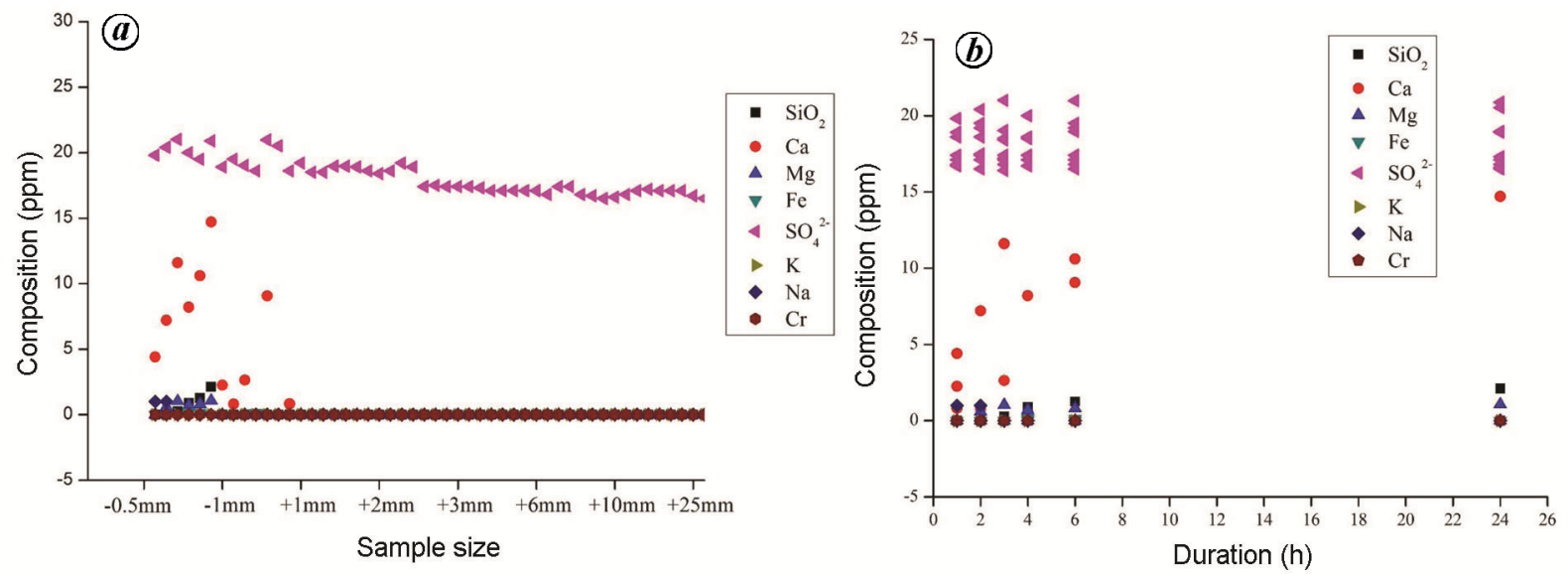

Figure 3. $\boldsymbol{a}$, Leaching analysis of other elements from different size fractions of the slag in water in neutral $\mathrm{pH}$ condition. $\boldsymbol{b}$, Leaching analysis of other elements in water from the slag at different exposure duration.

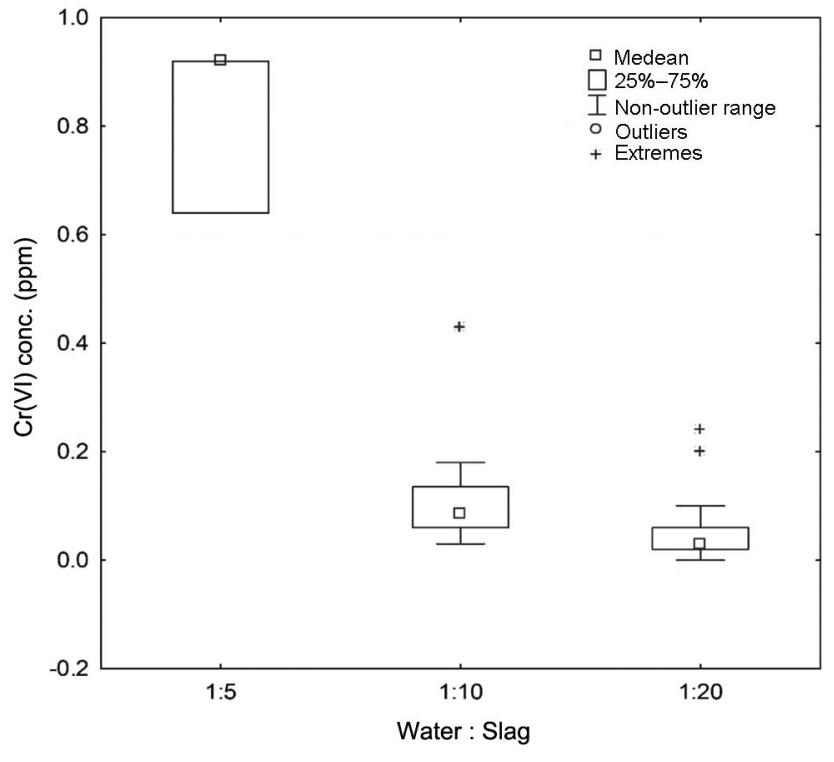

Figure 4. Concentration of $\mathrm{Cr}(\mathrm{VI})$ after adsorption experiment using $\mathrm{FeCr}$ slag in Sukinda water with variation in water/slag ratio as $1: 5$, $1: 10,1: 20$ (time: 60 min, $\mathrm{H}_{2} \mathrm{SO}_{4}$ used: $3 \mathrm{ml}$ ).

Table 3. Chemical analysis result of SCM processed water before and after the experiment

\begin{tabular}{lrr}
\hline & \multicolumn{2}{c}{ Concentration $(\mathrm{ppm})$ mean $\pm \mathrm{SE}$} \\
\cline { 2 - 3 } Parameters & \multicolumn{1}{c}{ Before treatment } & After treatment \\
\hline $\mathrm{Ca}$ & $16 \pm 0.45$ & $16 \pm 0.45$ \\
$\mathrm{Mg}$ & $46.23 \pm 0.07$ & $45 \pm 0.06$ \\
$\mathrm{SO}_{4}^{2-}$ & $1.7 \pm 0.45$ & $1.7 \pm 0.45$ \\
$\mathrm{SiO}^{2}$ & $30 \pm 0.45$ & $30 \pm 0.45$ \\
$\mathrm{Total} \mathrm{Cr}$ & $2.52 \pm 0.071$ & $2.46 \pm 0.04$ \\
$\mathrm{Fe}$ & $<0.001$ & $<0.001$ \\
$\mathrm{Cr}(\mathrm{VI})$ & $2.52 \pm 0.071$ & $0.01 \pm 0.03$ \\
$\mathrm{TDS}$ & $290 \pm 0.0089$ & $290 \pm 0.080$ \\
$\mathrm{pH}$ & $8.48 \pm 0.0089$ & $4.89 \pm 0.0085$ \\
\hline
\end{tabular}

SE, Standard error. Data represents mean \pm SE (standard error) of $n=5 ; * P<0.05, * * * P<0.001$ (Student's $t$-test).
IS limits. A similar observation was reported by Lind et $a l .{ }^{38}$.

\section{TCLP test}

In USEPA's TCLP, Cr(VI) limit was $0.1 \mathrm{mg} / 1$ and total chromium was $5.0 \mathrm{mg} / \mathrm{l}$ (ref. 32). This test is used to determine whether the waste is hazardous or nonhazardous. TCLP results showed that $\mathrm{Cr}$ concentration in TCLP extract was $0.045 \mathrm{mg} / \mathrm{l}$ which fitted with the USEPA limit and consistent with those reported by other researchers ${ }^{1,14,25}$. According to the regulatory TCLP test, $\mathrm{FeCr}$ slag is a non-hazardous element.

\section{Reduction of $\mathrm{Cr}(\mathrm{VI})$ by $\mathrm{FeCr}$ slag}

The elemental analysis of Sukinda water sample results on the initial day and after the experiment is shown in Table 3. The $\mathrm{pH}$ and TDS were found to be 8.48 and 290 ppm respectively, which were consistent with the report by Saha et al. ${ }^{31}$. Cr(VI) concentration was $2.52 \mathrm{ppm}$ which exceeded the permissible limit of hexachrome, i.e. $0.05 \mathrm{ppm}$. After the experiment, it was observed that $99 \%$ of $\mathrm{Cr}(\mathrm{VI})$ was reduced along with reduction of other elements also. It is well-established that $\mathrm{Cr}(\mathrm{VI})$ species predominate at basic $\mathrm{pH}$ range $\mathrm{e}^{8-10}$. Chromium formation in wastewater depends on $\mathrm{pH}$, type of waste and process involved. $\mathrm{Cr}$ (III) species predominate at acidic $\mathrm{pH}$ whereas in basic $\mathrm{pH}$, as in $\mathrm{SCM}$ water, $\mathrm{Cr}(\mathrm{VI})$ species like $\mathrm{CrO}_{4}^{2-}$, $\mathrm{HCrO}_{4}^{-}$or $\mathrm{Cr}_{2} \mathrm{O}_{7}^{2-}$ are present. The chromium speciation depends on $\mathrm{pH}$ and concentration of $\mathrm{Cr}(\mathrm{VI})^{39}$.

Series of batch experiments were done to find out the effect of water to slag ratio, amount of $\mathrm{H}_{2} \mathrm{SO}_{4}$ and duration for the reduction of $\mathrm{Cr}(\mathrm{VI})$ concentration by $\mathrm{FeCr}$ slag. These three parameters were found to be important to measure the $\mathrm{Cr}(\mathrm{VI})$ reduction capacity of $\mathrm{FeCr}$ slag. To 

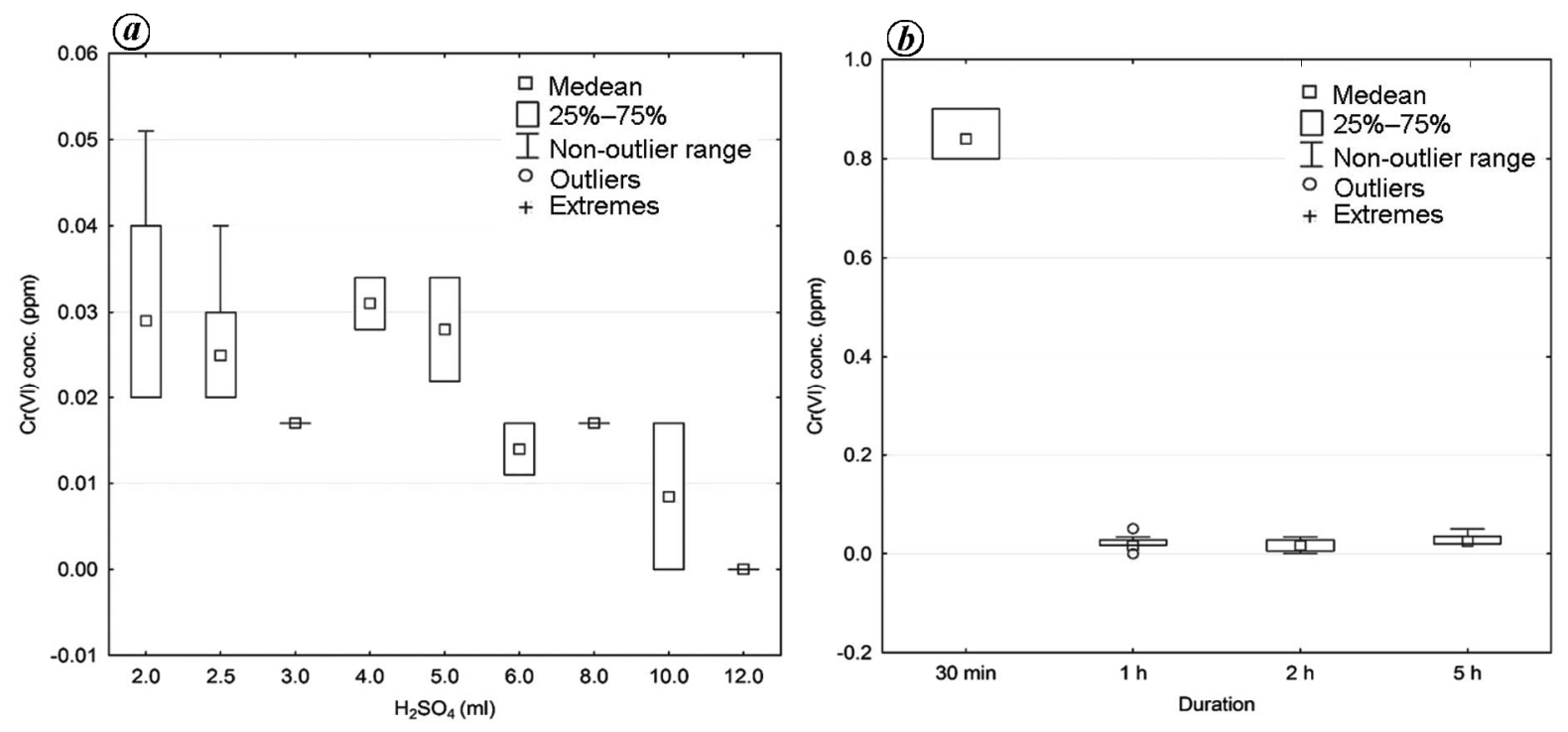

Figure 5. a , Effect of oxidizing agent on the reduction of $\mathrm{Cr}(\mathrm{VI})$. $\boldsymbol{b}$, Effect of time interval on the reduction of $\mathrm{Cr}(\mathrm{VI})$.

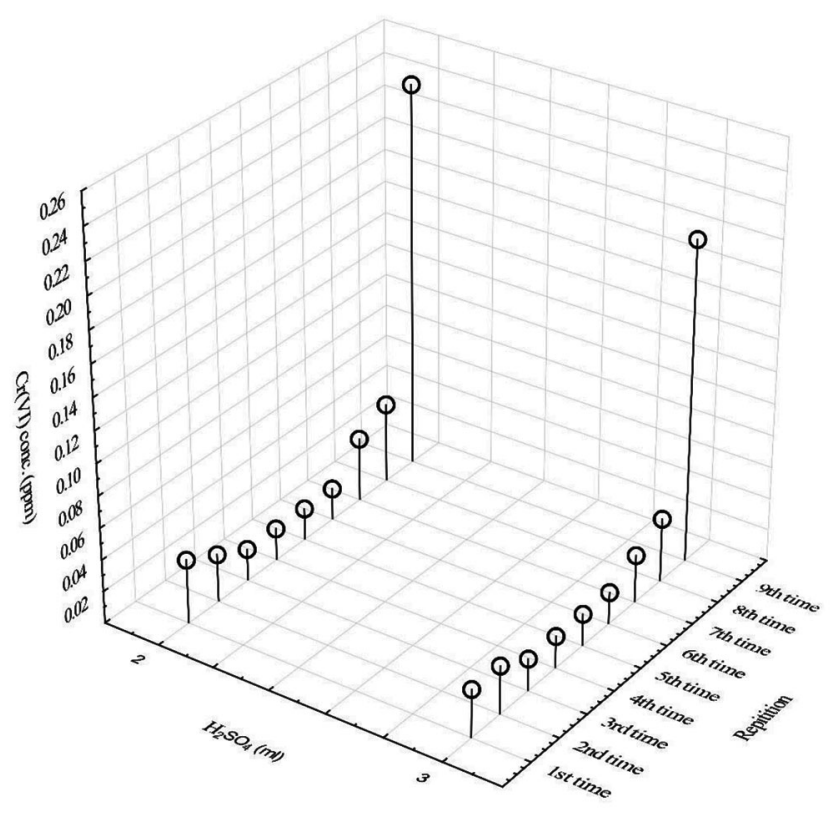

Figure 6. Recovery of $\mathrm{FeCr}$ slag.

increase the reduction efficiency, addition of $\mathrm{H}_{2} \mathrm{SO}_{4}$ is a common modification step ${ }^{40}$. Water to slag ratio varied as $1: 5,1: 10$ and $1: 20$. Experimental data showed that $\mathrm{Cr}$ (VI) reduction was maximum when water to slag ratio was $1: 20$ (Figure 4). Most of the cases of 1, 2 and $5 \mathrm{~h}$ stirring of slag in Sukinda water showed excellent reduction of $\mathrm{Cr}(\mathrm{VI})$ up to $99 \%$. However, for $30 \mathrm{~min}, \mathrm{Cr}(\mathrm{VI})$ reduction was limited to $40 \%, 45 \%, 47 \%$ for 2,3 and $4 \mathrm{ml}$ of $5 \mathrm{M} \mathrm{H}_{2} \mathrm{SO}_{4}$ applied respectively. One hour was found to be the sufficient duration for $\mathrm{Cr}(\mathrm{VI})$ removal with $96 \%$ efficiency for $2 \mathrm{ml} \mathrm{H}_{2} \mathrm{SO}_{4}$ used and 99\% for $3 \mathrm{ml} \mathrm{H}_{2} \mathrm{SO}_{4}$ used. Other parameters were also optimized

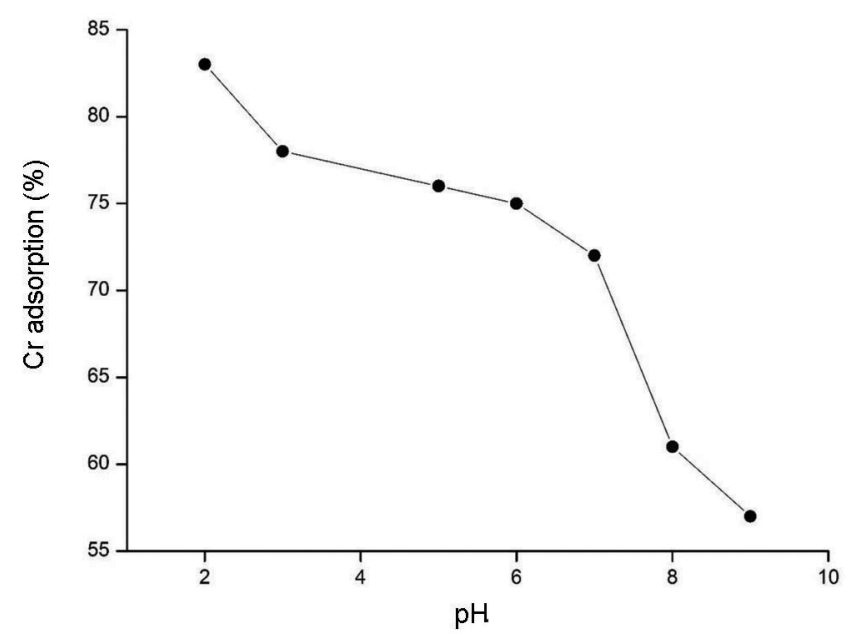

Figure 7. $\mathrm{Cr}(\mathrm{VI})$ adsorption efficiency of the $\mathrm{FeCr}$ slag with variations of solution $\mathrm{pH}(10 \mathrm{~g} / \mathrm{l} \mathrm{slag}, 5 \mathrm{ppm}$ standard $\mathrm{Cr}(\mathrm{VI})$ solution, $\mathrm{pH}$ range 2-9).

to observe the effect of oxidizing agent and time interval on the reduction of $\mathrm{Cr}(\mathrm{VI})$ (Figure $5 a$ and $b$ ). The used $\mathrm{FeCr}$ slag did not lose reduction capacity up to eight cycles of application with the residual Cr(VI) concentration remaining within the IS: 10500: 2012 limit of $0.05 \mathrm{mg} / \mathrm{l}$ (Figure 6). After the 9th cycle, the residual $\mathrm{Cr}(\mathrm{VI})$ concentration exceeded the permissible limit. $\mathrm{pH}$ of SCM water before experiment was 8.48 and it was reduced to $\sim 4.5$ after the addition of $\mathrm{H}_{2} \mathrm{SO}_{4}$. The $\mathrm{pH}$ did not change during the experiment. The used $\mathrm{FeCr}$ slag was again analysed for chemical composition which further proved that there was negligible leaching of $\mathrm{Cr}(\mathrm{VI})$ from the slag.

Some of the previous studies ${ }^{25}$ and experiments with standard $\mathrm{Cr}(\mathrm{VI})$ solution showed that FeCr slag was able 
to reduce almost $100 \% \mathrm{Cr}(\mathrm{VI})$ in as low as $15 \mathrm{~min}$ with the help of $\mathrm{H}_{2} \mathrm{SO}_{4}$. In a standard solution, there are no interferences present whereas in mining wastewater, several other elements were present which caused slower reduction in our experiments. Our aim was to reduce the chemical cost for valuable utilization of slag. Slag being a waste material is dumped and is available in plenty for convenient use in wastewater treatment. Increase in the TDS value can be explained by the action of $\mathrm{H}_{2} \mathrm{SO}_{4}$ on the iron content in the slag which can result in the formation of ferrous sulphate. Ferrous sulphate is a chemical precipitating agent commonly used in industries to chemically reduce $\mathrm{Cr}(\mathrm{VI})$ to $\mathrm{Cr}(\mathrm{III})^{41}$. Ferrochrome slag works as a matrix in $\mathrm{Cr}(\mathrm{VI})$ reduction to $\mathrm{Cr}(\mathrm{III})$ and precipitates $\mathrm{Cr}$ (III) which is non-toxic.

The real mechanism behind this reduction process is in situ generation of ferrous sulphate by the reaction of sulphuric acid and iron present in the $\mathrm{FeCr}$ slag. Therefore, in situ generated ferrous sulphate has the capability to reduce $\mathrm{Cr}(\mathrm{VI})$ to $\mathrm{Cr}(\mathrm{III})$. After treatment, there is no generation of sludge as generally formed in the normal ferrous sulphate treatment.

\section{pH optimization of $\mathrm{FeCr}$ slag for $\mathrm{Cr}(\mathrm{VI})$ removal}

$\mathrm{pH}$ is a dictating parameter for chromium sorption. The point of zero charge $\left(\mathrm{pH}_{\mathrm{PZC}}\right)$ of $\mathrm{FeCr}$ slag is at $\mathrm{pH}$, where the value of $\Delta \mathrm{pH}$ is zero. Natale et al. ${ }^{13}$ also found that $\mathrm{Cr}$ adsorption capacity was maximum between $\mathrm{pH} 6$ and 7. The value of $\mathrm{pH}_{\mathrm{PZC}}$ is important in understanding the adsorption mechanism. At $\mathrm{pH}<\mathrm{pH}_{\mathrm{PZC}}$, adsorption of anions is dominant while for cations it is at $\mathrm{pH}>\mathrm{pH}_{\mathrm{PZC}}$. From Figure 7 it is evident that $\mathrm{Cr}$ (VI) removal efficiency of $\mathrm{FeCr}$ slag is enhanced in the acidic $\mathrm{pH}$ range (2-6). Chromium ions coexist mainly as anions at acidic $\mathrm{pH}$ range. At low $\mathrm{pH}$, there is excess release of $\mathrm{H}^{+}$ions, which causes a strong electrostatic attraction between chromium anions and positively charged adsorbent surface and the increased adsorption in acidic $\mathrm{pH}$ range facilitates this process. However, in high $\mathrm{pH}$, lower rate of adsorption mainly occurs due to the competition between anions (chromate ions and $\mathrm{OH}^{-}$) in getting adsorbed on the adsorbent surface which is positively charged, when $\mathrm{OH}^{-}$predominates. Thus, it can be concluded from both the experiments, that the $\mathrm{Cr}(\mathrm{VI})$ adsorption is facilitated in low $\mathrm{pH}$.

\section{Sorption isotherm and adsorption kinetics}

$\mathrm{Cr}$ (VI) removal percentage increases with the increase in mesh number due to the increase in surface area of adsorbent, thereby providing more active sites available for adsorption. Based on the equilibrium data of adsorption experiment, the Langmuir isotherm exhibits better fitted model than Freundlich and Temkin isotherms, as the value of linear regression correlation $\left(R^{2}=0.98\right)$ was found highest for Langmuir type of isotherm (Figure $8 a$ ). Monolayer $\mathrm{Cr}(\mathrm{VI})$ adsorption takes place on the homogenous surface of $\mathrm{FeCr}$ slag containing the uniform distribution of active sites for adsorption in spite of any surface modifications. Previously Strkalj et al. ${ }^{27}$ and Saki et $a l^{28}$ got similar results in case of chromium adsorption by steel slag. Sarkar et al. ${ }^{42}$ also found the Langmuir isothermal model to be the best to explain hexavalent chromium adsorption by organoclay sorbent. Langmuir equation is

$$
\frac{C_{e}}{q_{e}}=\frac{C_{e}}{q_{m}}+\frac{1}{K_{\mathrm{L}} \times q_{m}},
$$

where $q_{e}$ is the amount adsorbed at equilibrium $(\mathrm{mg} / \mathrm{g})$, $C_{e}$ the equilibrium concentration of the adsorbate $(\mathrm{mg} / \mathrm{l})$, $q_{m}(\mathrm{mg} / \mathrm{g})$ and $K_{\mathrm{L}}$ are constants.

The adsorption kinetics was analysed by comparing the experimental data for two common models (pseudo-firstorder and pseudo-second-order kinetic model). These kinetic models are applicable to adsorption studies by correlation coefficient, $R^{2}$ value. Here, $R^{2}$ values for pseudo-second-order model were $>0.99$ (Figure $8 \mathrm{~b}$ ), which is higher than $R^{2}$ values for pseudo-first-order kinetic model. Therefore, the adsorption kinetics of $\mathrm{Cr}(\mathrm{VI})$ on $\mathrm{FeCr}$ slag is more convincingly explained by pseudo-second-order kinetic model. Strkalj et al. ${ }^{27}$ and Saki et $a l .{ }^{28}$ got similar results for steel slag. Sarkar et $a{ }^{42}$ found that pseudo-second-order kinetic model was ideal to explain hexavalent chromium adsorption by organoclay sorbent. Pseudo-second-order equation is

$$
\frac{t}{q_{t}}=\frac{1}{k_{2} q_{e}^{2}}+\frac{t}{q_{e}},
$$

where $q_{e}$ and $q_{t}$ are the amount adsorbed $(\mathrm{mg} / \mathrm{g})$ at equilibrium at any time $t$ and $k_{2}$ is the constant.

The $\mathrm{Cr}(\mathrm{VI})$ binding affinity $\left(K_{\mathrm{L}}\right)$ of $\mathrm{FeCr}$ slag was found to be $1.062 \mathrm{mg} / \mathrm{l}$, which denotes the affinity of the active sites of the adsorbent. Therefore, it suggests that after the monolayer adsorption on homogenous active sites of adsorbent based on their binding affinity, the saturation takes place in active sites, resulting in no further adsorption.

\section{Physical and geotechnical characterization of $\mathrm{FeCr}$ slag}

Any material to be used in road making has to be strong enough to bear the load. The physical and geotechnical characteristics of $\mathrm{FeCr}$ slag obtained are tabulated in Table 4 along with their standard tests to be followed. 

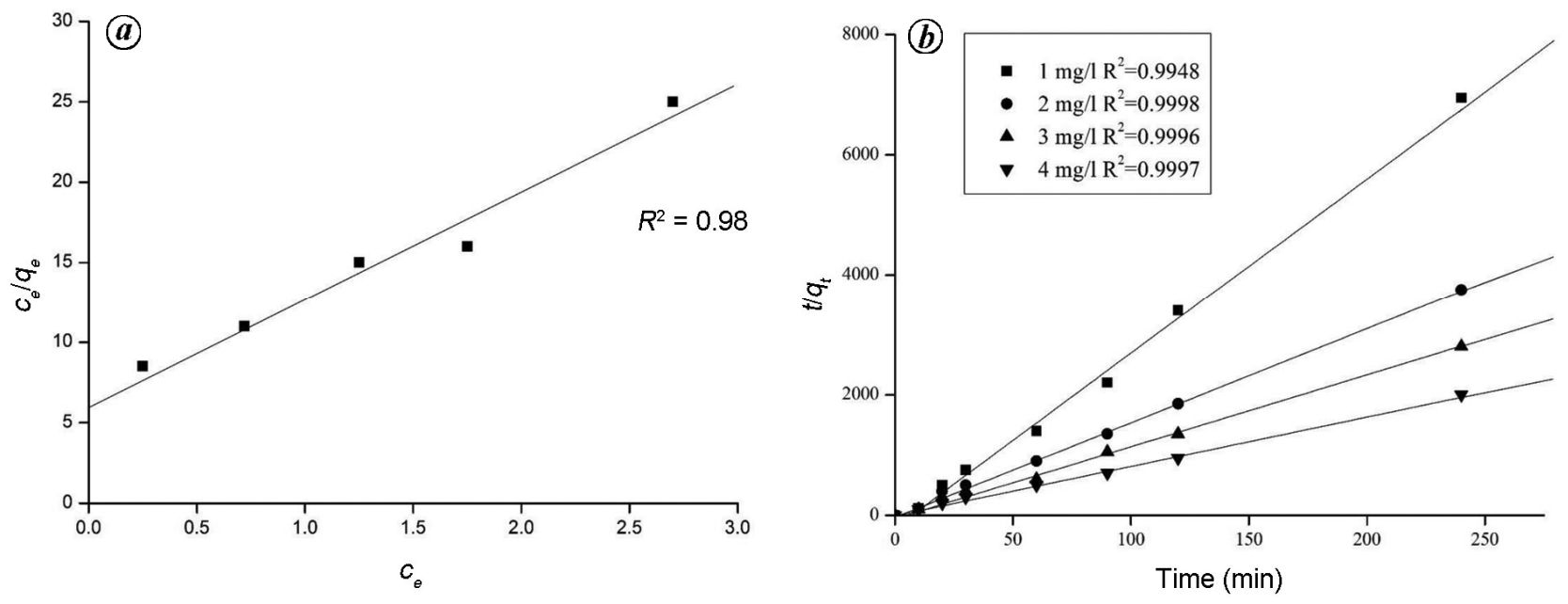

Figure 8. $\boldsymbol{a}$, Plot of Langmuir isotherm model $\left(R^{2}=0.98\right)(10 \mathrm{~g} / \mathrm{l} \mathrm{slag}$, standard $\mathrm{Cr}(\mathrm{VI})$ solutions in the range $1-4 \mathrm{mg} / \mathrm{l}$, pH $=2$, equilibrium time $60 \mathrm{~min})$. $\boldsymbol{b}$, Plot of pseudo second-order-kinetic model $\left(R^{2}=0.99\right)(10 \mathrm{~g} / 1 \mathrm{slag}$, standard $\mathrm{Cr}(\mathrm{VI}) \mathrm{solutions}$ in the range $1-4 \mathrm{mg} / \mathrm{l}$, $\mathrm{pH}=2)$.

Table 4. Physical and geotechnical characteristics of ferrochrome slag

\begin{tabular}{|c|c|c|}
\hline Parameters & Results & Standards to be followed \\
\hline Particle size distribution & $\begin{array}{l}\text { Gravel }(>4.75 \mathrm{~mm}): 28 \% \\
\quad \text { coarse sand }(4.75-2.00 \mathrm{~mm}): 25 \% \\
\text { medium sand }(2.00-0.425 \mathrm{~mm}): 30 \% \\
\text { fine sand }(0.425-0.075 \mathrm{~mm}): 12 \% ; \text { Silt, } 5 \%\end{array}$ & IS: 2720 (Part IV) - 1985 \\
\hline Permeability test & Coefficient of permeability: $6.445 \times 10^{-3} \mathrm{~cm} / \mathrm{sec}$ & IS: 2720 (Part XVII) - 1987 \\
\hline Bulk density & $\begin{array}{l}\gamma \text { bulk: } 2.02 \mathrm{~g} / \mathrm{cc} \text { at optimum moisture content (OMC) } \\
\text { and maximum dry density (MDD) }\end{array}$ & IS: 2386 (Part III) - 1963 \\
\hline Water absorption & $17.50 \%(\mathrm{NMC}: 1.82 \%)$ & IS: 2386 (Part III) - 1963 \\
\hline Void ratio & $e_{0}=0.515$ & IS: 2386 (Part III) - 1963 \\
\hline Compaction characteristics (Proctor test) & MDD - $1.78 \mathrm{~g} / \mathrm{cc} ; \mathrm{OMC}-13.72 \%$ & IS: 2720 (Part III) - 1986 \\
\hline Shape test (flakiness, elongation, angularity) & $\begin{array}{l}\text { Flakiness: } 53 \% \text {; elongation: } 8.8 \% \text {; angularity: } \\
\text { size is not available, material size considered: } \\
6.3 \mathrm{~mm} \text { and above; available max. size } 25.0 \mathrm{~mm}\end{array}$ & IS: 2386 (Part I) - 1963 \\
\hline Crushing value & Crushing: $40.02 \%$ & IS: 2386 (Part IV) - 1963 \\
\hline Specific gravity & Specific gravity $=2.79$ & IS: 2720 Part III Sec $2-1980$ \\
\hline $\mathrm{pH}$ value & $\mathrm{pH}=8.98$ & IS: 2720 (Part I) - 1983 \\
\hline Cation exchange capacity & $16 \mathrm{meq} / 100 \mathrm{~g}$ & IS: $2720-24$ (Part XXIV) - 1976 \\
\hline Direct shear test & $c=0$ and $\varphi=38^{\circ}$ & IS: 2720 (Part XXXIX) - 1977 \\
\hline
\end{tabular}

\begin{tabular}{|c|c|c|c|c|c|c|}
\hline \multirow[b]{2}{*}{$\begin{array}{l}\text { Compressive strength }\left(\mathrm{N} / \mathrm{mm}^{2}\right) \\
\text { California bearing ratio }\end{array}$} & \multirow{2}{*}{$\begin{array}{l}\text { Results on } \\
7 \text { days }\end{array}$} & \multirow{2}{*}{$\begin{array}{l}\text { Cement taken } \\
\text { OPC } 43 \text { Grade }\end{array}$} & \multicolumn{2}{|c|}{$\begin{array}{l}\text { Ratio taken } 1: 3 \\
\text { (cement : slag) }\end{array}$} & \multirow{2}{*}{$\begin{array}{l}\text { Limit } \\
33.00\end{array}$} & \multirow[b]{2}{*}{ IS: 2720 (Part XVI) - 1986} \\
\hline & & & $\begin{array}{l}29.00 \\
26.40 \\
27.60\end{array}$ & 27.67 & & \\
\hline California bearing ratio & $\begin{array}{l}\text { Unsoaked } \\
\text { Soaked }\end{array}$ & $\begin{array}{l}\text { At } 2.50 \mathrm{~mm} \text { per } \\
\text { At } 5.00 \mathrm{~mm} \text { per } \\
\text { At } 2.50 \mathrm{~mm} \text { per } \\
\text { At } 5.00 \mathrm{~mm} \text { per }\end{array}$ & $\begin{array}{l}: 23.20 \% \text {; } \\
: 21.80 \% \\
: 20.20 \% \text {; } \\
: 18.80 \%\end{array}$ & & & IS: 2720 (Part XVI) - 1986 \\
\hline Abrasive value & Abrasion: 1 & & & & & IS: 2386 (Part IV) - 1963 \\
\hline Impact value & Trial 1: 21 & Trial 2: $25.72 \%$ & & & & IS: 2386 (Part IV) - 1963 \\
\hline Relative density & $\begin{array}{l}\gamma_{\min }: 1.45 \mathrm{~g} \\
\text { Relative de }\end{array}$ & $\begin{array}{l}\text { ax: } 1.75 \mathrm{~g} / \mathrm{cc} \\
1.65 \mathrm{~g} / \mathrm{cc}\end{array}$ & & & & IS: 2386 (Part III) - 1963 \\
\hline Shear strength (parameters) & $c=0$ and $\varphi$ & & & & & IS: 2720 (Part XXXIX) - 1977 \\
\hline Free swelling index & Nil & & & & & IS: 2720 , Part XL \\
\hline Atterberg limit test & Non-plastic & rial & & & & IS: 2720, Part V \\
\hline
\end{tabular}


RESEARCH ARTICLES

Table 5. Compressive strength of used FeCr slag

\begin{tabular}{|c|c|c|c|c|c|}
\hline Parameter & & & Results & & \\
\hline \multirow[t]{2}{*}{ Compressive strength $\left(\mathrm{N} / \mathrm{mm}^{2}\right)$} & 7 days & Cement taken & $\begin{array}{l}\text { Ration taken } 1: 3 \\
\text { (cement : slag) }\end{array}$ & Average & Limit (as per IS: 8112-1989) \\
\hline & & OPC 43 grade & $\begin{array}{l}28.76 \\
29.78 \\
29.67\end{array}$ & 29.40 & 33 \\
\hline
\end{tabular}

All of the parameters were almost in agreement with IS values and so the slag is usable in road making. It has excellent compaction characteristics and swelling index is nil. Only concern is with the specific gravity value which was found marginally higher with respect to the standard value and it should be taken into consideration during design. Another promising result found was that, after reduction reaction used $\mathrm{FeCr}$ slag with cement in $3: 1$ ratio, it showed good compressive strength $\left(27 \mathrm{~N} / \mathrm{mm}^{2}\right)$. It could be used as a construction material if compressive strength is increased to $33 \mathrm{~N} / \mathrm{mm}^{2}$ (Table 5). Lind et al. ${ }^{38}$ and Ferreira et $a l^{43}$ showed the use and environmental impact of steel slags as secondary raw material in road construction.

\section{Conclusion}

Valuable utilization of $\mathrm{FeCr}$ slag was a challenging task for us. Experimental data inferred that FeCr slag could be utilized as an effective reducing agent of $\mathrm{Cr}(\mathrm{VI})$ for chromite mining wastewater. About $99 \% \mathrm{Cr}(\mathrm{VI})$ removal is accomplished with the help of FeCr slag. The mechanism behind the reduction reaction is in situ generation of ferrous sulphate by addition of small amount of oxidizing agent which helps to reduce the hexavalent chromium to trivalent chromium in water. Leaching analysis also supported that the used slag could be utilized as land filling material. Geotechnical data revealed that after reduction, used $\mathrm{FeCr}$ slag in combination with cement in $3: 1$ ratio can be used in landfill. This cost-effective system saves high chemical expenditure and can be employed even in remote areas without any basic infrastructure. TCLP data also supported that this waste is non-hazardous.

1. Gericke, W. A., Environmental solutions to waste products from ferrochrome production. In Proceedings of the Eighth International Ferroalloys Congress (INFACON 8), Session A, Beijing, China, 1998, pp. 51-58.

2. Testa, J. J., Grela, M. A. and Litter, M. I., Heterogeneous photocatalytic reduction of chromium(VI) over $\mathrm{TiO}_{2}$ particles in the presence of oxalate: involvement of $\mathrm{Cr}(\mathrm{V})$ species. Environ. Sci. Technol., 2004, 38(5), 1589-1594.

3. Lee, G. and Hering, J. G., Oxidative dissolution of chromium(III) hydroxide at $\mathrm{pH} 9,3$, and 2 with product Inhibition at $\mathrm{pH}$ 2. Environ. Sci. Technol., 2005, 39(13), 4921-4928.

4. McNeill, L. S., McLean, J. E., Parks, J. L. and Edwards, M., Hexavalent chromium review, part 2: chemistry, occurrence, and treatment. J. Am. Water Works Assoc., 2012, 104, 395-405.
5. Chen, G., Feng, J., Wang, W., Yin, Y. and Liu, H., Photocatalytic removal of hexavalent chromium by newly designed and highly reductive $\mathrm{TiO}_{2}$ nanocrystals. Water Res., 2017, 108, 383-390.

6. Stancl, H. O. N., Hristovski, K. and Westerhoff, P., Hexavalent chromium removal using $\mathrm{UV}-\mathrm{TiO}_{2} /$ ceramic membrane reactor. Environ. Eng. Sci., 2015, 32(8), 676-683.

7. Chebeir, M. and Liu, H., Kinetics and mechanisms of $\mathrm{Cr}(\mathrm{VI})$ formation via the oxidation of $\mathrm{Cr}$ (III) solid phases by chlorine in drinking water. Environ. Sci. Technol., 2016, 50(2), 701-710.

8. Tinjum, J. M., Benson, C. H. and Edil, T. B., Mobilization of $\mathrm{Cr}(\mathrm{VI})$ from chromite ore processing residue through acid treatment. Sci. Total Environ., 2008, 391(1), 13-25.

9. Wazne, M., Jagupilla, S. C., Moon, D. H., Christodoulatos, C. and Koutsospyros, A., Leaching mechanisms of $\mathrm{Cr}(\mathrm{VI})$ from chromite ore processing residue. J. Environ. Qual., 2002, 37, 2125-2134.

10. Weng, C. H., Huang, C. P. and Sanders, P. F., Effect of pH on $\mathrm{Cr}(\mathrm{VI})$ leaching from soil enriched in chromite ore processing residue. Environ. Geochem. Health, 2001, 23, 207-211.

11. Henderson, T., Geochemical reduction of hexavalent chromiumin the trinity sand aquifer. Ground Water, 1994, 32, 477-486.

12. Dermatas, D. and Moon, D. F., Chromium leaching and immobilization in treated soils. Environ. Eng. Sci., 2006, 23, 77-87.

13. Natale, F., Di Erto, A., Lancia, A. and Musmarra, D., Equilibrium and dynamic study on hexavalent chromium adsorption onto activated carbon. J. Hazard. Mater., 2015, 281, 47-55.

14. Panda, C. R., Mishra, K. K., Nayak, B. D., Rao, D. S. and Nayak, B. B., Release behaviour of chromium from ferrochrome slag. Int. J. Environ. Technol. Manage., 2012, 15, 261-274.

15. IBM (Indian Bureau of Mines), Annual Report of IBM, 2010, Govt of India.

16. Pattanaik, R. B., Pattanaik, S., Das, D. K. and Panda, M., Environmental scenario of chromite ore mining at Sukinda valley beyond 2030. Discov. Sci., 2012, 1(2), 35-39.

17. Mishra, H. and Sahu, H. B., Environmental scenario of chromite mining at Sukinda Valley - a review. Int. J. Environ. Eng. Manage, 2013, 4, 287-292.

18. Lazaridis, N. K. and Asouhidou, D. D., Kinetics of sorptive removal of chromium(VI) from aqueous solutions by calcined $\mathrm{Mg}-\mathrm{Al}-\mathrm{CO}_{3}$ hydrotalcite. Water Res., 2003, 37(12), 2875-2882.

19. Li, Y., Gao, B., Wu, T., Sun, D., Li, X., Wang, B. and Lu, F., Hexavalent chromium removal from aqueous solution by adsorption on aluminum magnesium mixed hydroxide. Water Res., 2009, 43, 3067-3075.

20. Mor, S., Ravindra, K. and Bishnoi, N. R., Adsorption of chromium from aqueous solution by activated alumina and activated charcoal. Bioresource Technol., 2007, 98(4), 954-957.

21. Gupta, V. K., Agarwal, S. and Saleh, T. A., Chromium removal by combining the magnetic properties of iron oxide with adsorption properties of carbon nanotubes. Water Res., 2011, 45, 2207-2212.

22. Wen, Y., Tang, Z., Chen, Y. and Gu, Y., Adsorption of Cr(VI) from aqueous solutions using chitosan-coated fly ash composite as biosorbent. J. Chem. Eng., 2011, 175, 110-116.

23. Jiang, W., Pelaez, M., Dionysiou, D. D., Entezari, M. H., Tsoutsou, D. and O'Shea, K., Chromium(VI) removal by magnetite nanoparticles. J. Chem. Eng., 2013, 222, 527-533. 


\section{RESEARCH ARTICLES}

24. Sun, X., Yang, L., Li, Q., Liu, Z., Dong, T. and Liu, H., Polyethylenimine functionalized poly(vinyl alcohol) magnetic microspheres as a novel adsorbent for rapid removal of $\mathrm{Cr}(\mathrm{VI})$ from aqueous solution. J. Chem. Eng., 2015, 262, 101-108.

25. Erdem, M., Altundoğan, H. S., Turan, M. D. and Tümen, F., Hexavalent chromium removal by ferrochromium slag. J. Hazard. Mater., 2005, 126, 176-182.

26. Agarwal, A., Gupta, V., Rathor, M. and Kumar, B., Removal of $\mathrm{Cr}$ (VI) from their aqueous solution by using brass industry waste (slag) as an adsorbent. Adv. Appl. Sci. Res., 2013, 4, 105-108.

27. Strkalj, A., Glavas, Z. and Matijasic, G., Adsorption of hexavalent chromium from an aqueous solution of steel-making slag. Mater. Technol., 2014, 48, 619-622.

28. Saki, P., Mafigholami, R., Takdastan, A. and Khoshkhoo, E., Adsorption of chromium from aqueous solution by steel slag: kinetic modeling and isotherm adsorption. Indian J. Public Health, 2014, 12, 51-60.

29. APHA, AWWA, WEF, Standard Methods for the Examination of Water and Wastewater, American Public Health Association, Washington (DC), 2005, 21st edn.

30. Palma, L., Di Gueye, M. T. and Petrucci, E., Hexavalent chromium reduction in contaminated soil: a comparison between ferrous sulphate and nanoscale zero-valent iron. J. Hazard. Mater., 2015, 281, 70-76.

31. Saha, P., Shinde, O. and Sarkar, S., Phytoremediation of industrial mines wastewater using water hyacinth. Int. J. Phytoremediat., 2016, 19(1), 87-96.

32. USEPA, Toxicity characterization leaching procedure (TCLP), EPA Method 1311, Washington, USA, 1990.

33. Winer, B. J., Statistical Principles in Experimental Design, International Student Edition, London, UK, 1981.

34. Shadreck, M. and Tawanda, M., Speciation of chromium in soils, plants and waste water at a ferrochrome slag dump in Gweru. IOSR J. Environ. Sci. Toxicol. Food Technol., 2013, 7(4), 43-49.

35. Tanskanen, P. A. and Makkonen, H. T., Applied mineralogy and petrology - examples of useful methods for slag composition and property design. In Fourth European Slag Conference, Oulu, 2005, pp. 71-82.

36. Sahu, N., Biswas, A. and Kapure, A short review on utilization of ferrochromium slag. Min. Proc. Ext. Metall. Rev., 2016, 37, 211219.
37. Kilau, H. W. and Shah, I. D., Chromium-bearing waste slag: evaluation of leachability when exposed to simulated acid precipitation. In Hazardous and Industrial Waste Management Testing, ASTM STP, third symposium, ASTM International, Pennsylvania, USA, 1984, 851, 61-80.

38. Lind, B. B., Fällman, A. M. and Larsson, L. B., Environmental impact of ferrochrome slag in road construction. Waste Manage., 2000, 1, 247-259.

39. Dhal, B., Thatoi, H. N., Das, N. N. and Pandey, B. D., Chemical and microbial remediation of hexavalent chromium from contaminated soil and mining/metallurgical solid waste: a review. J. Hazar. Mater., 2013, 250-251, 272-291.

40. Anbalagan, K., Kumar, P. S. and Karthikeyan, R., Desalination and water treatment adsorption of toxic $\mathrm{Cr}(\mathrm{VI})$ ions from aqueous solution by sulphuric acid modified Strychnos potatorum seeds in batch and column studies. Desalin. Water Treat., 2015, 57(27), 12585-12607.

41. Sowmya, P. T., Mahadevraju, G. K., Ramesh, A. and Sreenivas, V., Removal of hexavalent chromium from industrial waste water by chemical treatment. Int. J. Innov. Res. Dev., 2013, 2, 1440 1446.

42. Sarkar, B., Xi, Y., Megharaj, M., Krishnamurti, G. S. R., Rajarathnam, D. and Naidu, R., Remediation of hexavalent chromium through adsorption by bentonite based Arquad® 2 HT-75 organoclays. J. Hazar. Mater., 2010, 183, 87-97.

43. Ferreira, V. J., Sáez-De-Guinoa Vilaplana, A., García-Armingol, T., Aranda-Usón, A., Lausín-González, C., López-Sabirón, A. M. and Ferreira, G., Evaluation of the steel slag incorporation as coarse aggregate for road construction: Technical requirements and environmental impact assessment. J. Clean. Prod., 2016, 130, $175-186$.

ACKNOWLEDGEMENTS. We thank the Research and Development of Tata Steel and the Department of Civil Engineering, Jadavpur University, Kolkata for the help and support.

Received 3 July 2018; revised accepted 28 January 2019

doi: $10.18520 / \mathrm{cs} / \mathrm{v} 116 / \mathrm{i} 9 / 1515-1524$ 